Halaman | 1

\title{
Isolasi, Uji Aktifitas Antibakteri dan Identifikasi Senyawa Aktif Kapang Endofit dari Tanaman Belimbing Manis (Averrhoa carambola L.)
} Isolation, Antibacterial Activity and Bioactive Compound Identification of Endophytic Fungi from Starfruit Plant (Averrhoa carambola L.)

Trisanti Anindyawati dan Dody Priadi

Pusat Penelitian Bioteknologi-LIPI,

Jl. Raya Bogor Km. 46 Cibinong 16911Telp. (021) 8754587 Fax. (021) 8754588

e-mail : atrisanti@yahoo.com

\section{Riwayat Naskah:}

Diterima 03,2017 Direvisi 06,2017 Disetujui 07,2017
ABSTRAK: Tanaman belimbing (Averrhoa carambola) memiliki potensi farmakologis, antara lain sebagai senyawa antimikroba. Kapang endofit isolat A 1.1 yang diisolasi dari ranting tanaman belimbing, diuji potensinya sebagai antibakteri terhadap Bacillus subtilis, Staphylococcus aureus dan Eschericia coli. Uji antibakteri dilakukan dengan metoda difusi cakram. Analisis GC-MS dilakukan terhadap ekstrak etil asetat kapang endofit A 1.1 untuk identifikasi komponen kimianya. Hasil uji antibakteri menunjukkan bahwa ekstrak etil asetat dan ekstrak kloroform mampu menghambat pertumbuhan bakteri uji. Ekstrak etil asetat mempunyai aktivitas DDH (7,5 mm) lebih besar dibanding ekstrak kloroform $(6,10 \mathrm{~mm})$ terhadap B. subtilis. Hasil analisis GC-MS menunjukkan bahwa ekstrak etil asetat kapang endofit A 1.1 mengandung 17 komponen kimia. Komponen utamanya adalah 1-Octadecene, 1-Dococene dan 1-Hexadecene.

Kata kunci:A. carambola, kapang endofit, antibakteri, identifikasi

\begin{abstract}
Starfruit plant (Averrhoa carambola) has pharmacological properties, such as antimicrobial compounds. Endophytic fungi A 1.1 isolated from twigs of starfruit plants, was tested for its antibacterial potential against Bacillus subtilis, Staphylococcus aureus, and Escherichia coli. Theantibacterial assessment was conducted by disc diffusion method. The GC-MS analysis was carried out on A 1.1 ethyl acetate extract for identification of chemical components. The results showed that ethyl acetate and chloroform extracts were able to inhibit the growth of tested bacteria. The inhibition zone of ethyl acetate extract was $(7.5 \mathrm{~mm})$ larger than that of the chloroform extract $(6.10 \mathrm{~mm})$ against $B$. subtilis. The GC-MS analysis showed that the A 1.1 ethyl acetate extract contains 17 chemical components, and 1Octadecene, 1-Dococene, and 1-Hexadecene were the main components.
\end{abstract}

Keywords : A. carambola, endophytic fungi, antibacterial, identification

\section{Pendahuluan}

Tanaman belimbing manis (Averrhoa carambola) berasal dari daerah Amerika tropis tetapi sebagian besar peneliti menduga berasal dari daerah Asia Tenggara. Belimbing manis sekarang telah tersebar di daerah tropis dan subtropik basah. Rasa buahnya manis dan asam (Verheij, 1992). Genus Averrhoa terdiri dari dua spesies, yaitu $A$. carambola L. dan A. bilimbi L (Avinash et al., 2012). A. carambola adalah pohon yang tumbuh cepat. Beberapa varietas belimbing manis, telah dikarakterisasi secara genetik maupun fenotipik seperti varietas Malaysia, Penang, Rawasari, Bangkok, Sembiring, Dewabaru, Demak dan Dewimurni. Kekerabatan yang paling erat adalah antara varietas Malaysia dan Penang (Priadi et al., 2016). Varietas Dewimurni memiliki karakter yang unggul, yaitu rasanya manis asam, sedikit aromatik dan mengandung banyak air (Priadi \& Cahyani, 2011). Buah belimbing mempunyai sifat farmakologi sebagai antioksidan, antiinflamasi, antimikroba/antijamur, antitumor, antiulcer (Saghir et al., 2013)dan mempunyai aktivitas 
hipoglikemik, hipokolesterol dan hipolipid (Payal et al., 2012). Buah tanaman ini dapat digunakan untuk mengobati penyakit batuk, keracunan makanan, sakit tenggorokan dan juga dapat dimanfaatkansebagai obat untuk tekanan darah tinggi, menurunkan kadar kolesterol, mencegah kanker, memperlancar pencernaan, peluruh kencing, lemakdan radang usus (Wiryowidagdo \& Sitanggang, 2002). Beberapa senyawa yang terkandung dalam buah belimbing yangdapat menyebabkan efek farmakologis adalah satu atau gabungan beberapa senyawa kimia yang ada didalamnya, yaitu golongan flavonoid, alkaloid, saponin, protein, lemak, fosfor, zat besi serta vitamin A, B1 dan C (Wiryowidagdo \& Sitanggang, 2002).Akar tanaman ini dapat digunakan untuk mengobati sakit kepala kronis sedangkan daunnya dapat untuk mengobati bisul, pilek dan radang usus. Sementara bunganya dapat digunakan untuk mengobati demam dan malaria (Sung et al., 1998).

Tanaman merupakan inang bagi satu atau lebih mikroba endofit. Mikroba endofit adalah mikroba yang tumbuh pada jaringan tanaman dan hidup bersimbiosa saling menguntungkan dengan tanaman inangnya tanpa menimbulkan efek negatif (Stone at al., 2000). Pada setiap tanaman, dapat diperoleh lebih dari satu jenis mikroba, antara lain dari kelompok bakteri, kapang dan actinomycetes yang terutama berada di bawah jaringan lapisan sel epidermis (Strobel, 2003). Hubungan antara mikroba endofit dan tanaman inangnya terjadi karena kontribusi bahan kimia yang dihasilkan oleh mikroba dalam menghasilkan berbagai senyawa bioaktif metabolit sekunder seperti senyawa antimikroba, antioksidan, antibiotik dan antikanker yang sangat bermanfaat dalam industri farmasi (Strobel, 2003; Strobel etal., 2005). Identifikasi mikroba endofit telah dilakukan oleh Nursanty \&Iqbar (2013) pada jenis belimbing lain yaitu belimbing wuluh (A. bilimbi).

Produksi senyawa bioaktif dengan menggunakan mikroba jauh lebih mudah prosesnya dan bersahabat dengan alam, selain itu tidak perlu mengambil bahan baku dari alam sehingga penggunaannya lebih berkelanjutan. Proses produksi senyawa bioaktif dengan cara fermentasi menggunakan mikroba memiliki beberapa keuntungan, antara lain mikroba yang ditambahkan dalam bioreaktor dapat sesuai dengan kebutuhan, menghasilkan suplai yang terus menerus sehingga senyawa bioaktif dapat dihasilkan secara konsisten dan kontinyu. Selain itu, mikroba dapat hidup sesuai dengan sifatnya dan dapat dikultur cairkan secara rutin, peningkatan produktivitas relatif lebih mudah dilakukan dan senyawa bioaktif yang berbeda dapat dihasilkan dengan mengubah kondisi kultur (Petrini, 1992). Sampai saat ini, penelitian tentang bioaktivitas dari kapang endofit tanaman belimbing masih belum diketahui. Oleh sebab itu, dalam penelitian ini dilakukan isolasi, uji aktivitas antibakteri danidentifikasi senyawa bioaktif kapang endofit isolat A 1.1 dari ranting tanaman belimbing manis varietas Dewimurni.

\section{Bahan dan Metode}

\subsection{Bahan}

Bahan yang digunakan dalam penelitian ini adalah ranting tanaman belimbing manis ( $A$. carambola) varietas Dewimurni koleksi kebun Plasma Nutfah, Pusat Penelitian Bioteknologi-LIPI. Bahan media yang digunakan terdiri dari Corn Meal-Malt Extract Agar (CMM), Nutrient Agar (NA), Potato Dextrose Agar (PDA), Potato Dextrose Broth (PDB) dan Nutrient Broth (NB). Bakteri uji terdiri dari Bacillus subtilis, Staphylococcus aureus dan Eschericia coli. Bahan kimia terdiri dari etanol, sodium hipoklorit, kloramfenikol, etil asetat, kloroform, $n$-heksan dan bahan bahan kimia untuk analisis.

Peralatan yang digunakan dalam penelitian ini terdiri dari autoclave (Tomy), laminar air flow(Esco), pisau skalpel, pinset, inkubator (Memmert), timbangan analitik (Precisa), sentrifus (Jouan), peralatan gelas, hot plate(Thermolyne), rotavapor(Ikalabortechnik),kromatografi lapis tipis (KLT) $\mathrm{F}_{254} \quad$ (Merck) dankromatogafi gas spektrometri massa(GC-MS) (Agilent Technologies GC System 6890N dengan Mass Selective Detector 5973 Inert).

\subsection{Metode}

\subsubsection{Isolasi mikroba endofit}

Isolasi kapang endofit dari ranting segar tanaman dilakukan dengan cara memotong ranting tanaman dengan ukuran kurang lebih $1 \mathrm{~cm}$, kemudian dicuci dengan air mengalir sampai bersih (Petrini, 1992). Selanjutnya, potongan-potongan ranting tersebut disterilkan permukaannya dengan cara dicelupkan berturut turut pada larutan 75\% etanol selama 1 menit, 5,3\% sodium hipoklorit dan sekali lagi ke dalam larutan etanol 75\%. Pekerjaan tersebut dilakukan secara aseptik dalam laminar airflow. Setelah itu, potongan ranting dikeringkan dengan menggunakan kertas tissue sterildan dibelah menjadi dua bagian. Satu bagian ranting diletakkan pada media CMM yang mengandung kloramfenikol $(0,005 \% \mathrm{~b} / \mathrm{v})$ dan satu bagian lainnya diletakkan pada media NA. Selanjutnya, media dalam petri tersebut diinkubasi pada suhu $27^{\circ} \mathrm{C}$ selama $1-3$ minggu sampai terlihat adanya pertumbuhan bakteri atau kapang. Setelah itu, kapang/bakteri dimurnikan dengan jalan memindahkan ke agar miring PDA untuk kapang dan NA untuk bakteri. 
Halaman | 3

\subsubsection{Kultivasi dan ekstraksi kapang endofit isolat $A$ 1.1}

Kapang endofit dengan kode isolat A 1.1 yang diisolasi dari ranting tanaman belimbing ditumbuhkan dan dimurnikan pada media PDA. Setelah tumbuh baik pada fase konstan, kapang dipindahkan pada media pertumbuhan yaitu pada300 ml media cair PDB yang telah disterilkan. Proses inkubasi dilakukan pada suhu $27^{\circ} \mathrm{C}$ menggunakan pengocok dengan kecepatan 120 rpm selama 14 hari. Selanjutnya dilakukan proses pemisahan antara filtrat dan biomasa dengan menggunakankertas saring.Proses ekstraksi dilakukan dengan cara menambahkan pelarut yang berbeda yaitu masing masing dengan etil asetat, kloroform dan $n$-heksan teknis dengan perbandingan antara pelarut dan sampel 1:1. Proses pengocokan ini dilakukan kurang lebih 2 jam dan setelah itu dipisahkan dengan menggunakan labu pisah dan didiamkan beberapa saat sampai terjadi pemisahan yang sempurna. Proses ini dilakukan sebanyak 3 kali agar kandungan senyawa yang dihasilkan dapat terekstrak dengan sempurna.Masing masing ekstrak selanjutnya dipekatkan dengan rotavapor.

\subsubsection{Uji aktivitas antibakteri}

Mikroba uji yang digunakan adalah bakteri patogen yang masing masing mewakili bakteri Gram positif dan Gram negatif, yaitu B. subtilis, $S$. aureus dan E. coli. Metoda difusi cakram digunakan untuk uji senyawa antibakteri. Setelah mikroba tumbuh baik pada mediapertumbuhan NA, kemudian ditumbuhkan pada $3 \mathrm{ml}$ media NB dan diinkubasi pada suhu $37^{\circ} \mathrm{C}$ selama semalam dengan agitasi $120 \mathrm{rpm}$. Mikroba patogen B. subtilis (0,1\%), E. coli $(0,2 \%)$ dan $S$. aureus $(0,1 \%)$ masing masing kemudian ditumbuhkan dengan cara mengocok pada $8 \mathrm{ml}$ media NA lunak (1,15\%) yang merupakan bagian atas dari media NA dua lapis. Bagian bawah dari media tersebut (10ml) merupakan media NA (2,3\%). Setelah agar memadat, sampel yang merupakan ekstrak sebanyak $10 \mu$ diteteskan pada cakram dan setelah dikering-anginkan, cakram tersebut ditaruh diatas media yang telah mengandung bakteri. Kontrol positif yang digunakan adalah kloramfenikol dan kontrol negatif yang digunakan adalah masing masing pelarut.

\subsubsection{Analisis senyawa kimia dengan KLT}

Analisis komponen kimia yang terdapat dalam ekstrak etil asetat jamur endofit A 1.1 dilakukan dengan metode KLT. Ekstrak ditotol pada lempeng $(1 \mu \mathrm{l})$ dan dimasukkan dalam chamber dengan menggunakan fase gerak $n$-heksan : etil asetat (5:1).
Eluen dibiarkan merambat sampai batas atas dan kemudian dikering-anginkan. Selanjutnya bercak yang timbul pada lempeng diamati dengan menggunakan UV pada panjang gelombang $254 \mathrm{~nm}$ dan $366 \mathrm{~nm}$ dan setelah itu lempeng disemprot larutan serium sulfat $1 \%$. Setelah kering, lempeng dipanaskan pada suhu $110^{\circ} \mathrm{C}$ selama kurang lebih 5 menit sampai terlihat adanya bercak.

\subsubsection{Proses pemurnian}

Proses pemurnian terhadap ekstrak etil asetat dilakukan dengan menggunakan kolom gelas (23 $\mathrm{x}$ $1,5 \mathrm{~cm}$ ) yang berisi silika. Silika dicampur dengan pelarut $n$-heksan, kemudian dituang dalam kolom. Setelah kolom siap digunakan, sampel etil asetat dimasukkan secara perlahan lahan dan ditambahkan pelarut yang sama, kemudian dilanjutkan secara berturut turut gradient $n$-heksan : etil asetat dengan perbandingan $10: 1 ; 8: 1 ; 6: 1$; $4: 1 ; 2: 1$ dan $1: 1$ dan setelah itu dengan etil asetat 100\%. Fraksi ditampung dalam botol vial dengan volume masing masing $3 \mathrm{ml}$ dan dianalisis menggunakan KLT untuk selanjutnya dikelompokkan berdasarkan Retention factor (Rf) yang sama.

\subsubsection{Identifikasi senyawa dengan GC-MS}

Fraksi terpilih kemudian diidentifikasi dengan GC-MS. Sampel sebanyak $3 \mu$ diinjeksikan pada alat dengan temperatur oven $70^{\circ} \mathrm{C}$ dengan rata rata kenaikan $15^{\circ} \mathrm{C} /$ menit sampai mencapai final $290^{\circ} \mathrm{C}$. Temperatur kolom $350^{\circ} \mathrm{C}$ dengan laju alir $1 \mathrm{ml} /$ menit.Kolom yangdigunakan adalah Agilent 190915-436 HP-5MS dengan ukuran 0,25 mm x 60 $\mathrm{m} \times 0,25 \mu \mathrm{m}$. Gas pembawa adalah helium. Komponen kimia yang ada selanjutnya diidentifikasi dengan menggunakan database Wiley 7n.1.

\section{Hasil dan Pembahasan}

\subsection{Skrining dan isolasi senyawa bioaktif dari kapang endofit}

Hasil skrining secara makroskopik (visual) dari keempat isolat kapang endofit, yaitu isolat A 1.1, A 1.2, A 1.3 dan A 1.4 menunjukkan bahwa isolat kapang endofit A 1.1 mempunyai tingkat pertumbuhan yang paling tinggi $(+4)$ pada hari ke 7, dibandingkan ketiga isolat lainnya (Tabel 1).

Tabel 1.

Pertumbuhan berbagai isolat kapang endofit

\begin{tabular}{ccc}
\hline No & Isolat & Pertumbuhan \\
\hline 1 & A 1.1 & ++++ \\
2 & A 1.2 & ++ \\
3 & A 1.3 & +++ \\
4 & A 1.4 & ++ \\
\hline
\end{tabular}


Isolat tersebut (Gambar 1) mempunyai aktivitas paling besar sehingga baik dikembangkan untuk menghasilkan senyawa bioaktif. Pertumbuhan kapang endofit tergolong lambat dibandingkan kapang pada umumnya, kurang lebih tumbuh sekitar 7 hari pada suhu $27^{\circ} \mathrm{C}$. Pertumbuhan mikroorganisma dalam menghasilkansenyawa metabolit sekunder terjadi pada fase stasioner/ konstan (Madigan et al., 1997). Proses fermentasi dilakukan dengan cara agitasi bertujuan untuk meningkatkan suplai oksigen dalam medium sehingga menjadi homogen. Untuk memperoleh senyawa bioaktif dari kapang endofit dilakukan ekstraksi menggunakan pelarut yang berbeda tingkat kepolarannya, yaitu etil asetat dan kloroform (semi polar) serta $n$-heksan (non polar).

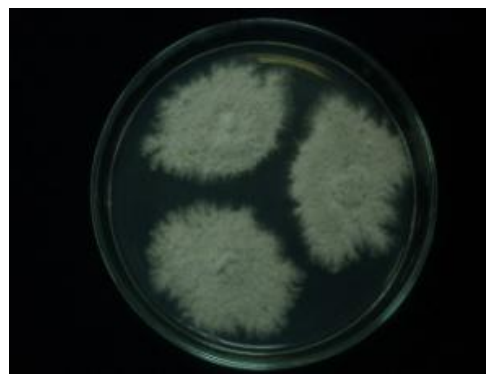

Gambar 1. Kapang endofit isolat A 1.1 pada media PDA

\subsection{Uji aktivitas antibakteri}

Berdasarkan hasil uji aktivitas antibakteri terhadap bakteri patogen $B$. subtilis, $S$. aureus dan $E$. coli, maka ekstrak etil asetat dan kloroform mampu menghambat pertumbuhan ketiga bakteri uji. Pada Tabel 2, terlihat bahwa ekstrak etil asetat mempunyai zona penghambatan lebih besar terhadap bakteri Gram positif ( $S$. aureus) daripada zona yang dihasilkan oleh bakteri Gram negatif, akan tetapi ekstrak kloroform mempunyai zona penghambatan yang relatif sama antara bakteri Gram negatif dan positif. Zona hambat ekstrak etil asetat terhadap B.subtilis, $S$. aureus dan E. coli berturut-turut adalah 7,15 mm, 6,43 $\mathrm{mm}$ dan 6,20 mm. Ekstrak etil asetat dan ekstrak kloroform mempunyai kemampuan dalam menghambat pertumbuhan bakteri uji, sedangkan ekstrak dari $n$ heksan tidak menunjukkan kemampuan dalam menghasilkan zona hambat. Jadi senyawa aktif yang bersifat antibakteri dari ranting tanaman belimbing manis isolat A 1.1 merupakan senyawa yang bersifat semi polar. Hal tersebut terlihat dari zona hambat terbesar dihasilkan oleh ekstrak etil asetat yang bersifat semi polar. Dilaporkan bahwa ekstrak metanol dan aseton dari buah belimbing lebih baik daya hambatnya terhadap bakteri Gram positif dibandingkan bakteri Gram negatif(Payal et al., 2012). Bakteri uji yang digunakan merupakan bakteri yang bersifat patogen terhadap manusia. $B$. subtilis dan E. coli dapat menyebabkan penyakit diare, sedangkan $S$. aureus mempunyai kemampuan membentuk toksin penyebab keracunan makanan dan penyakit kulit. Hal tersebut kemungkinan disebabkan struktur sel yang berbeda. Struktur sel pada bakteri Gram positif relatif lebih sederhana, hanya terdiri dari 3 lapis yaitu selaput sitoplasma, lapisan peptidoglikan dan lapisan sinpai, sedangkan pada bakteri Gram negatif lapisannya lebih kompleks (Jawetz et al., 1996).

Tabel 2.

Diameter zona hambat dari kapang endofit A 1.1 terhadap bakteri patogen

\begin{tabular}{cccc}
\hline \multirow{2}{*}{ Pengekstrak } & \multicolumn{3}{c}{ Zona hambat (mm) } \\
\cline { 2 - 4 } & B.subtilis & S.aureus & E.coli \\
\hline Etil asetat & 7,15 & 6,43 & 6,20 \\
Kloroform & 6,10 & 6,10 & 6,10 \\
$n$-heksan & - & - & - \\
\hline
\end{tabular}

3.3. Pemisahan dan identifikasi senyawa kimia dari kapang endofitA 1.1

Hasilpengamatan secara kualitatif menggunakan KLT menunjukkan bahwa ekstrak etil asetat mempunyai lebih dari satu komponen yang mengindikasikan bahwa didalam ekstrak kapang endofit tersebut terdapat lebih dari 1 komponen kimia. Hal ini ditunjukkan dengan terdeteksinya bercak berfluorensi yang terlihat dibawah sinar UV (Gambar2). Selanjutnya pemisahan sampel dilakukan dengan menggunakan kolom kromatografi. Kromatografi adalah suatu cara pemisahan senyawa dalam suatu campuran berdasarkan berat molekulnya. Hasil dari pemisahan kolom, terdapat 2 fraksi aktif yaitu fraksi A dan fraksi B. Fraksi A dan B kemudian dianalisis dengan KLT dan hasilnya menunjukkan bahwa fraksi A memiliki 1 bercak sedangkan fraksi B tidak terlihat adanya bercak. Berdasarkan hal tersebut, maka fraksi A diuji dengan menggunakan GC-MS.

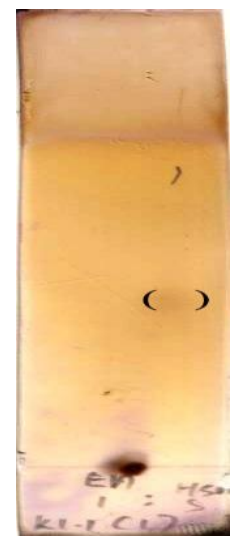

Gambar 2. Hasil uji KLT ekstrak etil asetat 
Hasil identifikasi fraksi A dari kapang endofit isolat A 1.1 yang diisolasi dari tanaman Belimbing manis varietas Dewimurni menunjukkan bahwa terdapat 17 senyawa yang mempunyai kualitas antara 95-99\% (Tabel 3), yaitu 1-Tetradecene, 1Hexadecene, diphenyl-Methanone, Heptadecane, Pentadecane,1-Octadecene, Nonadecane, Hexadecanoicacid,7,9-di-tert-butyl-1-oxaspiro[4.5]deca6,9-diene-2,8-dione,methyl-3-(3,5-ditert-butyl-4hydroxyphenyl) proprionate, 1-Docosene, Heneicosane, Octadecanoic acid, methyl ester, Tricosane, Pentacosane,Tetracosane dan Octacosane. Senyawa yang merupakangolongan alkana sebanyak 5 buah $(29,41 \%)$, golongan alkena 9 buah (52,94\%), golongan asam lemak 2 buah $(11,76 \%)$ dan golongan fenol 1 buah $(5,88 \%)$. Hasil kromatogram dari fraksi A dapat dilihat pada Gambar 3.

Berdasarkan hasil identifikasi, ternyata senyawa 1-Octadecene merupakan senyawa dengan luas area terbesar, yaitu $11,83 \%$ (Tabel 3). 1 Octadecene dari ekstrak aseton Spirulina platensis dilaporkan mempunyai aktivitas antibakteri terhadap bakteri patogen $S$. aureus dan S.typhimurium (Kumar et al., 2011). Disamping itu, senyawa 1-Octadecene yang diekstrak menggunakan diklorometan dari tanaman Thesiumhumile Vahl, berpotensi sebagaiantibakteri, antioksidan dan antikanker (Belakhdar et al., 2015). Senyawa Docosene dilaporkan mempunyai aktivitas antibakteri (Nandhini et al., 2015), sedangkan Hexadecene mempunyai aktivitas sebagai antibakteri, antifungi dan antioksidan (Akpuaka et al., 2013; Belakhdar et al., 2015). Selain itu, Hexadecanoic acid mempunyai aktivitas sebagai antioksidan, hipokolesterol, nematisida, pestisida, pelumas, antiandrogenik,hemolitik (Deshmukh \&Jadhav, 2013), juga sebagai inhibitor enzim 5- $\alpha$ reduktase (Elezabeth \& Arumugam, 2014a,b; Dandekar et al., 2015),antimikroba (Akpuakaet al., 2013), dan antiinflamasi (Malarvizhi, 2015). Heptadecane juga dilaporkan mempunyai aktivitas sebagai antioksidan dan antiinflamasi (Kim etal., 2013). Menurut Elezabeth \& Amuragam (2014b), Octadecanoic acid, methyl ester mempunyai aktivitas antioksidan. Selain itu, dilaporkan juga bahwa senyawa tersebut juga berpotensi sebagai antimikroba pada $\mathrm{pH}$ rendah (Akpuaka et al., 2013).Menurut Dandekar et al. (2015), senyawa Tetracosane mempunyai aktivitas sebagai antikorosif dan antioksidan, sedangkan senyawa Heneicosane mempunyai aktivitas sebagai antibakteri (Nandhini et al., 2015; Sharma et al., 2016). Dilaporkan bahwa ekstrak metanol buah belimbing manis mengandung senyawa golongan flavonoid, alkaloid dan saponin dengan kandungan utamanya golongan flavonoid (Sukadana, 2009).

\section{Kesimpulan}

Ekstrak etil asetat kapang endofit A 1.1 dari tanaman belimbing manis (A. carambola) mempunyai aktivitas antibakteri terhadap $B$. subtilis,S. aureus dan E.coli. Zona hambat ekstrak etil asetat dan ekstrak kloroform berturut turut adalah 7,15 dan 6,10 mm terhadap B. subtilis.Fraksi A dari ekstrak etil asetat mengandung 17 komponen senyawa dengan senyawa utamanya adalah 1-Octadecene, 1-Dococene dan 1Hexadecene.Senyawa pada ekstrak etil asetat dapat digolongkan menjadi senyawa alkana, alkena, asam lemak dan fenol.

$$
\text { A bundance }
$$

TIC: BELIM B IN G.D

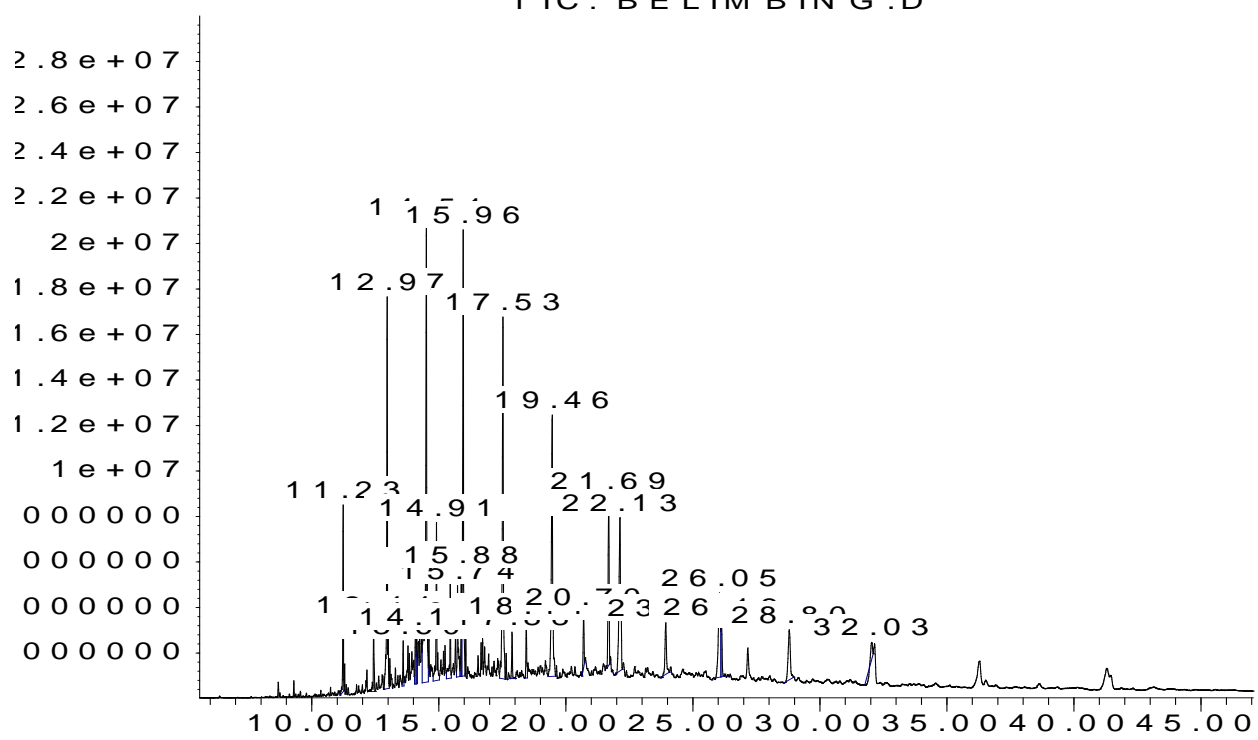

Tim e-->

Gambar 3.Kromatogram fraksi A pada GC-MS 
Tabel 3.

Identifikasi fraksi A menggunakan $G C-M S$

\begin{tabular}{|c|c|c|c|c|}
\hline No & $\begin{array}{l}\text { Waktu retensi } \\
\text { (menit) }\end{array}$ & $\begin{array}{c}\text { Luas area } \\
(\%)\end{array}$ & Perkiraan senyawa menurut Wiley7n. & Kualitas \\
\hline 1 & 11.2339 & 2.3511 & 1-Tetradecene & 99 \\
\hline 2 & 12.9669 & 6.7456 & 1-Hexadecene & 96 \\
\hline 3 & 13.5956 & 0.6065 & diphenyl-Methanone & 95 \\
\hline 4 & 13.7825 & 0.8572 & Heptadecane & 98 \\
\hline 5 & 13.8334 & 0.4754 & Pentadecane & 98 \\
\hline 6 & 14.5131 & 11.8324 & 1-Octadecene & 99 \\
\hline 7 & 15.2522 & 0.6517 & Nonadecane & 98 \\
\hline 8 & 15.456 & 2.1142 & Hexadecanoic acid & 98 \\
\hline 9 & 15.6514 & 0.8293 & 7,9-di-tert-butyl-1-oxaspiro[4,5]deca-6,9-diene-2,8-dione & 99 \\
\hline 10 & 15.7364 & 2.1767 & Methyl-3-(3,5-ditertbutyl-4-hydroxyphenyl) propionate & 98 \\
\hline 11 & 15.9573 & 8.6272 & 1-Docosene & 99 \\
\hline 12 & 16.7303 & 0.6579 & Heneicosane & 98 \\
\hline 13 & 16.9597 & 0.9478 & Octadecanoic acid, methyl ester & 96 \\
\hline 14 & 18.4464 & 0.8973 & Tricosane & 98 \\
\hline 15 & 20.7062 & 0.9424 & Pentacosane & 98 \\
\hline 16 & 28.8022 & 2.5896 & Tetracosane & 97 \\
\hline 17 & 26.1261 & 1.2493 & Octacosane & 99 \\
\hline
\end{tabular}

\section{Ucapan terima kasih}

Penulis mengucapkan terima kasih kepada Dr. Praptiwi atas diskusi dan saran yang telah diberikan dan Bustanussalam M.Si atas bantuan yang telah diberikan selama penelitian berlangsung.

\section{Daftar Pustaka}

Akpuaka, A., Ekwenchi, M.M., Dashak, D.A.\& Dildar, A. (2013). Biological Activities and Characterized Isolates of $n$-Hexane Extracts of Azadirachta indica A. Juss (Neem) Leaves. New York Sci. J.6(6), 119-124.

Avinash, P., Swapneei, K., Darshana, P.\&Anita, P. (2012). A Comprehensive Review of An Important Medicinal Plant Averrhoa carambola L. Pharmacog. Comm. Vol. 2(2), 13-17.

Belakhdar, G., Benjouad, A.\& Abdennebi, E.H. (2015). Determination of Some Bioactive Chemical Constituents from Thesium humile Vahl. J. Mater. Environ. Sci. 6(10), 2778-2783.

Dandekar, R., Fegade, R.\& Bhaskar VH. (2015). GC-MS Analysis of Phytoconstituents in Alcohol Extract of Epiphyllum oxypetalumLeaves. J. Pharmacog. \& Phytochem. 4(1), 149154.

Deshmukh, S.\& Jadhav, V. (2013). GC-MS Studies ofClitoria ternatea L.-A Medicinally ImportantPlant. American J. of Pharm. Res., 3(7), 5394-5399.

Elezabeth, D.V.\& Arumugam, S. (2014a).GC-MS Analysis of Ethanol Extract of Cyperus rotundus Leaves. Int'l J. Curr. Biotechnol.2(1), 19-23.

Elezabeth,D.V. \&Arumugam., S.(2014b). GC-MS Analysis of Bioactive Constituents of Indigofera suffruticosa Leaves. J. of Chem. Pharm. Res., 6, 294-300.

Jawetz, E., Melnick, L., Adelberg, E.A., Brooks, G.F., Butel, J.S. \& Ornston, N. Alih bahasa Nugroho, E dan Maulany, R.F. Editor Setyawati, I. (1996). Mikrobiologi Kedokteran. Penerbit Buku Kedokteran, Jakarta.

Kim, D. H., Park, M. H., Choi, Y. J., Chung, K. W., Park, C. H., Jang, E. J., An, H.J., Yu, B.P. \& Chung, H. Y. (2013). Molecular Study of Dietary Heptadecane for the Anti-inflammatory Modulation of NF-kB in the Aged Kidney.PloS one, 8(3),1-9.

Kumar, V., Bhatnagar, A.K.\&Srivastava, J.N. (2011). Antibacterial Activity of Crude Extract of Spirulina plantesis and Its Structural Elucidation of Bioactive Compound. J. of Med. Plants Res. 5(32), 7043-7048.

Nandhini, U. S., Sangareshwari, S., \& Lata, K. (2015). Gas Chromatography-Mass Spectrometry Analysis of Bioactive
Constituents from The Marine Streptomyces. Asian J. of Pharm. \& Clinical Res.8(2), 244-246.

Nursanty, R. \& Iqbar. (2013). Identifikasi Bakteri Endofit Asal Tanaman Belimbing Wuluh. Jurnal Ilmiah Pendidikan Biologi, Biologi Edukasi5(1),36-38.

Madigan, M.T., Martinko, J.M.\&Parker, J. (1997). Growth and Products Formation in Industrial Processes. Brock Biology of Microorganisms. Prentice Hall Int'l, p. 434-435.

Malarvizhi, D., Anusooriya, P., Meenakshi, P., Sowmya, S., Perumal, P. C., Oirere, E. K., \& Gopalakrishnan, V. K. (2015) Antioxidant Properties and Analysis of Bioactive Compounds Present in $n$-hexane Root Extract of Zaleya decandra.Int'l J. Pharm. Sci. Rev. Res., 34(2), 118-123.

Payal, G., Pankti, K., Manodeep, C.\& Jagadish, V.K. (2012) Phytochemical and Pharmacological Profile of Averrhoa carambola Linn: An Overview. Int'l Res. J. ofPharm. 3(1), 8892

Petrini, O., Sieber, T.N., Toti, L.\& Viret, O. (1992). Ecology, Metabolite Production and Substrate Utilization in Endophytic Fungi. Nature Toxin 1, 185-196.

Priadi, D., Perdani, A., Sulistyowati, Y., Pohan, F., \&Mulyaningsih, E. (2016). Characterization of Carambola (Averrhoa carambola) Plant Collection of Cibinong Plant Germplasm Garden Based on Phenotypic and Genetic Characters.Biosaintifika8(1), 121-128.

Priadi, D.\& Cahyani, Y. (2011). Keanekaragaman Varietas Belimbing Manis (Averrhoa carambola L.) di Kebun Plasma Nutfah Tumbuhan dan Hewan Cibinong. Berk. Penel. Hayati Edisi Khusus 5A, 73-77.

Saghir, S.A.M., Sadikun, A., Khaw, K-Y. \&Murugaiyah, V. (2013). Star Fruit (Averrhoa carambola L.): From Traditional Uses to PharmalogicalActivities. Bul. Latino. Caribe Plantas Med. Arom. 12(3), 209-219.

Sharma, D., Pramanik, A., \& Agrawal, P. K. (2016). Evaluation of Bioactive Secondary Metabolites from Endophytic Fungus Pestalotiopsis neglecta BAB-5510 Isolated from Leaves of Cupressus torulosa D. Don. 3 Biotech, 6(2), 210.

Stone, J.K., Bacon, C.W.\&White, J.F. Jr., (2000): An Overview of Endophytic Microbes: Endophytic Difined, 3-29 in Bacon, C.W and White, J.F. Jr. (ed). Microbial Endophytes. Marcel Dekker Inc. New York.

Strobel, G.A. (2003). Endophytes as Source of Bioactive Products. Microbes and Infection 5, 535-544

Strobel, G., Daisy, B. \&Castillo, U. (2005). The Biological Promise of Microbial Endophytes and Their Natural Products. Plant Pathology J. 4(2), 161-176.

Sukadana, I.M. (2009). Senyawa Antibakteri Golongan Flavonoid dari Buah Belimbing Manis (Averrhoa carambola Linn). Jurnal Kimia 3(2), 109-116. 
Halaman | 7

Warta IHP/Journal of Agro-based Industry Vol.34 (No.1) 07 2017: 1-7

Sung, C.K., Kimura, T., But P.P.H.\&Guo, J-X. (1998). Int'l Collation of Traditionaland Folk Medicine: Northeast Asia, Singapore. World Scientific Publishing Company, 75-76.

Verheij, E.W.M.\& Coronel, R.E. (1992). Plant Resources of SouthEast Asia No.2: Edible Fruits and Nuts. PROSEA, Bogor Indonesia p. 447.
Wiryowidagdo, S.\&Sitanggang, M. (2002). Tanaman Obat Untuk Penyakit Jantung, Darah Tinggi dan Kolesterol. Agro Media, Jakarta. 